\title{
Farmer Producing Organizations for Development of Farmers in India: An Economic Perspective
}

\author{
N.P. Darshan ${ }^{1 *}$, B. Rajashekar ${ }^{1}$, K.V. Patil ${ }^{1}$, K.N. Ravi ${ }^{2}$ and J. Parameshwar Naik ${ }^{3}$ \\ ${ }^{1}$ Department of Agricultural Extension, PJTSAU, Hyderabad, Telangana, India \\ ${ }^{2}$ Department of Agricultural Extension, BHU, Varanasi, U.P., India \\ ${ }^{3}$ Department of Agricultural Extension, NDRI, Karnal, Haryana, India \\ *Corresponding author
}

\section{A B S T R A C T}

\begin{tabular}{|c|}
\hline Keywords \\
\hline $\begin{array}{l}\text { FPOs, Income, } \\
\text { Savings, Reducing } \\
\text { costs, Marketing } \\
\text { intelligence. }\end{array}$ \\
\hline Article Info \\
\hline $\begin{array}{l}\text { Accepted: } \\
\text { 19 July } 2017 \\
\text { Available Online: } \\
\text { 10 September } 2017\end{array}$ \\
\hline
\end{tabular}

The present paper was written based on analysis of secondary data of various cases of FPOs in South India. A total of five FPOs were selected and reviewed based on the set objectives. The analysis revealed that there are about 683 FPOs in India. Individual cases revealed that FPOs have been helping a boon for farmers as it enhanced the income of farmers, enable savings by reducing the input, transportation and labour costs. It has also helped them enhancing their marketing intelligence.

\section{Introduction}

India had over 138 million farm holdings as per the Agricultural Census, 2011 (GoI, Agricultural census, 2011). Of this, about 92.8 million were marginal farm holdings i.e. having individual operational land holding of less than 1 hectare while another about 24.8 million were small farm holdings with individual operational and holding size between 1 to 2 hectares. Therefore, the marginal and small farm holdings together accounted for a whopping 85.0 percent of the total farm holdings in India in 2010-11 (GoI, Agricultural census 2011).However, their share in the country's total operated area was only 44.6percent. On a national average, the
Size of operational land holding of each farm varied from 0.39 hectare in the case of the marginal farm holdings to1.42 hectares for small farm holdings to 17.38 hectares in the case of the large farm holdings, which worked out to 1.15 hectares for all farm holding groups taken together. Such is the predominance of small farms in Indian agriculture. As per estimates, about 1.5to 2.0 million new marginal and small farms are being added every year due to continued land fragmentation (NAC, 2012).

Small Farmers' Agribusiness Consortium (SFAC), a Society promoted by Dept. of 
Agriculture, Govt. of India, has been nominated by Ministry of Agriculture to act as a nodal agency to coordinate with various State governments, civil society partners, private sector, financial institutions, resource persons and other stakeholders to help in the conduct of baseline studies to promote Farmer Producer Organizations (FPOs) across the country and link producer groups (both existing ones and newly formed institutions) to marketing opportunities. SFAC has initiated FPO with the purpose to collectivise farmers, especially small producers, at various levels across several states, to foster technology penetration, improve productivity, enable improved access to inputs and services and increase farmer incomes, thereby strengthening their sustainable agriculture based livelihoods.

The international development agencies including the UN agencies such as World Bank, UNDP and FAO have also been showing their interest in investing in these organizations. Many of the non-government organizations (NGOs) in the country had been facilitating formation of producer organizations and in the recent years some of them have graduated to facilitate formation of producer companies on behalf of the state governments and development funding agencies.

In the above background, this paper aims at analysing the spread of FPOs in India and their performances in terms of economic benefits to farmers.

\section{The study initiated with the following objectives}

To understand the current status of the producer organisation and their spread across the India, and

To examine the performance of the existing producer organisations on various economic parameters and in terms of improving net incomes and market power of small and marginal farmers.

\section{Materials and Methods}

Secondary data was collected from various sources of government websites and authenticated sources and were analysed. Over 6 case studies of FPOs from various states of India are analysed and the results were presented.

\section{Results and Discussion}

Madhya Pradesh, Maharashtra, Karnataka, West Bengal and Odisha, form the top five states in terms of number of FPO's. This may be due to active involvement of NGO's and developing agencies for initiating and sustaining FPO, and continuous funding from SFAC (Table 1).

\section{Analysis of cases of FPOS}

\section{Jain Hanuman Samruddhi Utpadak Samuh: Madhya Pradesh}

The Supporting Resource Institution of Jain Hanuman Samruddhi Utpadak Samuh is Indian Grameen Services (IGS). This farmer interest group was started with 14 farmers by opening a bank account in its name.

They started saving ' 100 on monthly basis. They purchased 250 bags of DAP at ' 1000 per bag against market price of INR.1115 per bag. Their total saving was 28,750 on just DAP alone.

Over time, this group has also helped in the formation of FIGs in other villages and, today, all the village-level primary groups have come together and formed a producer company to increase their bargaining power and to get benefits of aggregation at an even higher level. 
Krishak Janhit Samiti and others: New Delhi

The Supporting Resource Institution of Krishak Janhit Samitiis International Traceability Systems Limited (ITSL). 1639 progressive farmers of 89 FIGs have been growing brinjal, spinach, sponge gourd and cabbage among others.

Prior to the introduction to this scheme they would sell their produce at the Agricultural Produce Marketing Committee (APMC), Azadpur, where they felt cheated because the 'adhtiyas' or commission agents deduct a certain volume of produce for weight loss and sampling.

When they got tied up with Bharti Walmart collection centre, they started earning profits and they extended their links with Mother Dairy and Reliance Fresh. They have sold $1,558 \mathrm{mt}, 2,273 \mathrm{mt}$ and1, $322 \mathrm{mt}$ of produce at Bharti Walmart, Mother Dairy and Reliance Fresh, respectively so far in 2013. They have overcome the lacunae of APMCs.

Ekta Group Vegetable and Fruits Production and Marketing Cooperative Ltd: Gujarat

The supporting resource institution (RI) of Ekta Group Vegetable and Fruits Production and Marketing Cooperative Ltd is Development Support Centre (DSC).

This Gujrat based FIG employed the collective marketing of vegetables and started selling in a night market in Ahmedabad instead of regular day market.

Their transportation cost was reduced to Rs. 0.75 per $\mathrm{kg}$, instead of previous cost of Rs. 1.80 per $\mathrm{kg}$ when vegetables were sold individually. It also reduced their labour cost of loading and unloading by 3 per cent.

\section{Krishikabandhu farmer producer company Ltd: Karnataka}

\section{Supporting Resource Institution (RI): Vrutti Livelihood Resource Centre (VLRC)}

Farmers suffered loss in Tur farming due drought erratic rainfall and pest attacks. After the intervention of VLRC, they started adopting new technology by developing a separate nursery to grow Tur seedlings and transplanted them. They also followed intercropping with maize or marigold. In one acre, on an average a farmer incurred a transplantation cost of Rs. 10,000 but grew 7 quintals of red gram instead of 4 quintals in traditional method and also earned Rs. 4000 from intercrop of Maize. By adopting new method their income got doubled.

\section{Vrindavan Pushpa Utpadak Sangh: Maharashtra}

The supporting resource institution of Vrindavan Pushpa Utpadak Sanghis Bharatiya Agro Industries Foundation (BAIF).This Maharashtra based FPO adopted floriculture by growing Jasmine flowers. Farmers sell their produce collectively according to prevailing daily flower rates in the market. The traders pay the Sangh every month based on the prevailing rates for each day. The amount received from the trader is deposited in the Sangh's bank account. Members are paid on a monthly, basis after deducting the expenditure incurred on marketing. Each member contributes Rs. 10 per $\mathrm{kg}$ of flower sold, towards the sustainability fund of the Sangh which is, in turn, used to purchase input material for cultivation. The input material is provided to the members at a cost.

About 1,904 farmers are involved in floriculture as an income-generation activity in Thane. Over the years, the farmers have 
earned more than Rs. 2 crore from selling jasmine. The profits have improved the standards of living, education and health of the farmers.

Table.1 Selected state-wise progress of farmer producer organisations (FPOs) promotion in India (As on 24.07.2015)

\begin{tabular}{|c|c|c|c|c|c|c|}
\hline \multirow[t]{2}{*}{ States } & \multicolumn{3}{|c|}{ Number of Farmers } & \multicolumn{3}{|c|}{ Number of FPOs } \\
\hline & Mobilized & $\begin{array}{c}\text { Under } \\
\text { Mobilization }\end{array}$ & Total & Registered & $\begin{array}{c}\text { Under the } \\
\text { Process of } \\
\text { Registration }\end{array}$ & Total \\
\hline $\begin{array}{l}\text { Andhra } \\
\text { Pradesh }\end{array}$ & 976 & 6024 & 7000 & 0 & 7 & 7 \\
\hline $\begin{array}{l}\text { Arunachal } \\
\text { Pradesh }\end{array}$ & 1750 & 0 & 1750 & 2 & 0 & 2 \\
\hline Bihar & 14244 & 3756 & 18000 & 8 & 11 & 19 \\
\hline Chhattisgarh & 13293 & 12707 & 26000 & 5 & 20 & 25 \\
\hline Delhi & 3535 & 0 & 3500 & 4 & 0 & 4 \\
\hline Goa & 1810 & 0 & 1750 & 1 & 1 & 2 \\
\hline Gujarat & 19487 & 513 & 20000 & 10 & 11 & 21 \\
\hline Haryana & 9598 & 0 & 11750 & 16 & 9 & 25 \\
\hline $\begin{array}{l}\text { Himachal } \\
\text { Pradesh }\end{array}$ & 3698 & 1152 & 4850 & 0 & 4 & 4 \\
\hline Jammu & 3694 & 287 & 3981 & 1 & 2 & 3 \\
\hline Srinagar & 3120 & 960 & 4080 & 1 & 3 & 4 \\
\hline Jharkhand & 10009 & 0 & 10000 & 8 & 0 & 8 \\
\hline Karnataka & 25904 & 58596 & 84500 & 14 & 68 & 82 \\
\hline $\begin{array}{l}\text { Madhya } \\
\text { Pradesh }\end{array}$ & 83277 & 61723 & 145000 & 67 & 77 & 144 \\
\hline Maharashtra & 63166 & 28334 & 91500 & 49 & 43 & 92 \\
\hline Manipur & 2650 & 300 & 2950 & 2 & 1 & 3 \\
\hline Meghalaya & 2615 & 1135 & 3750 & 2 & 2 & 4 \\
\hline Mizoram & 1700 & 1000 & 2700 & 0 & 3 & 3 \\
\hline Nagaland & 1750 & 0 & 1750 & 2 & 0 & 2 \\
\hline Odisha & 28121 & 10779 & 38900 & 15 & 27 & 42 \\
\hline Punjab & 6288 & 0 & 6000 & 7 & 0 & 7 \\
\hline Rajasthan & 40277 & 6223 & 46500 & 31 & 7 & 38 \\
\hline Sikkim & 1876 & 0 & 1750 & 2 & 0 & 2 \\
\hline Tamil Nadu & 11626 & 0 & 11000 & 4 & 7 & 11 \\
\hline Telangana & 24374 & 0 & 23998 & 10 & 10 & 20 \\
\hline Tripura & 2874 & 0 & 2750 & 3 & 1 & 4 \\
\hline Uttarakhand & 6004 & 0 & 6000 & 7 & 0 & 7 \\
\hline Uttar Pradesh & 27453 & 7547 & 35000 & 25 & 6 & 31 \\
\hline West Bengal & 58598 & 10902 & 69500 & 21 & 46 & 67 \\
\hline India & 473767 & 211938 & 686209 & 317 & 366 & 683 \\
\hline
\end{tabular}

Source: Lok Sabha Unstarred Question No. 1250, dated on 28.07.2015. www.indiastat.com 


\section{Savitribai Mahila Self-help Group:} Maharashtra

The supporting Resource Institution of Savitribai Mahila Self-help Groupis Bharatiya Agro Industries Foundation (BAIF). Under the guidance of MITRA and BAIF a SHG consisting of local entrepreneurs and tribal farmers initiated a poultry hatchery unit. One month old chicks were given to tribal farmers for rearing which incur a cost of Rs. 40-45 per chick. The profits earned per chick were Rs. 15. By this SHG earned a profit of Rs. 13,500 per batch (1000 lot size, taking $10 \%$ mortality). This FPO has helped farmers and local entrepreneurs to effectively harness their additional income and provided selfemployment.

Analysis of cases of FPOs revealed a positive impact on the economic development of farmers. The FPOs have helped to organize the small and marginal farmers to improve their standards of living by providing assured income, employment, better technologies of production and post-harvest management activities. Since the collective action of farmers given positive results it can be advisable to initiate and sustain the FPOs across the country to improve the agricultural contribution to GDP and to retain small and marginal farmers in agriculture.

\section{References}

Financing farmers' producer organisations: A policy paper. UNDP, 2014. Retrieved fromhttp://www.livelihoodsasia.org/upl oads-livelihoodsasia/subsection_data/ financing-for-farmer-producerorganisations.pdf

Government of India, 2013a. State of Indian Agriculture 2012-13. (New Delhi: Ministry of Agriculture, Department of Agriculture and Cooperation, Directorate of Economics and statistics).

Krishisutra 2, 2013. Success stories of farmer producer organizations. Retrieved from http://sfacindia.com/PDFs/Krishi-Sutra (Version2).pdf.

Selected state-wise progress of Farmer Producer Organisations (FPOs) promotion in India (As on 24.07.2015). Retrieved from www.indiastat.com

\section{How to cite this article:}

Darshan, N.P., B. Rajashekar, K.V. Patil, K.N. Ravi and Parameshwar Naik, J. 2017. Farmer Producing Organisations for Development of Farmers in India: An Economic Perspective. Int.J.Curr.Microbiol.App.Sci. 6(9): 1611-1615. doi: https://doi.org/10.20546/ijcmas.2017.609.198 